\title{
Cancer Incidence in the Population Residing Near Nuclear Power Plants in India, - A Study From Tata Memorial Centre, Mumbai
}

\section{Research Article}

Keywords:

Posted Date: February 25th, 2021

DOI: https://doi.org/10.21203/rs.3.rs-152396/v2

License: (c) (1) This work is licensed under a Creative Commons Attribution 4.0 International License. Read Full License 


\section{Abstract}

The authors have requested that this preprint be withdrawn due to a need to make corrections.

\section{Full Text}

The authors have withdrawn this preprint from Research Square. 